\title{
Os coronéis - de Mendonça a Paulo Honório: notas sobre tipicidade e realismo em $S$. Bernardo
}

\author{
[ The "coronéis" - from Mendonça to Paulo Honório: notes \\ about typicality and realism in S. Bernardo.
}

\section{Hermenegildo Bastos ${ }^{\mathrm{I}}$}

RESUMo Considerando o legado modernista brasileiro, do qual foi um herdeiro sempre crítico, Graciliano Ramos em S. Bernardo faz o seu narrador-personagem vivenciar de modo dramático, e até o extremo, os problemas do escritor na luta por captar o sentido do destino humano em uma situação de degradação e achatamento da vida. Escrever se revela, ao final, como caminho para a compreensão do processo de desumanização. Mas, para tanto, é necessário que a escrita vá além da representação da mera singularidade e se encaminhe para a construção do tipo, entendido como uma forma capaz de iluminar as contradições. A teoria do tipo, ou da particularidade, como elaborada por Lukács, revela aqui o seu valor e atualidade. - PalavrasCHAVE S. Bernardo de Graciliano Ramos; a herança crítica do legado do Modernismo brasileiro; a escrita literária como caminho para o entendimento das contradições sociais; Lukács e a estética da particularidade. - ABSTRACT Considering the Brazilian modernist legacy, of which he was always a critic heir, Graciliano Ramos in S. Bernardo makes his narrator-character go through the writer's problems in the struggle to grasp the meaning of human fate, in a situation of life's degradation and flattening. Writing reveals itself in the end as the path to comprehending the process of dehumanization. But in order to achieve that, it is necessary to go beyond the representation of the mere singularity life and route itself to the construction of the type, understood as a capable way of shedding light upon the contradictions. The theory of the type, or particularity, as elaborated by Lukács, reveals here its value and actuality. - KEYwords Graciliano Ramos' S. Bernardo; critical heritage of Brazilian Modernism legacy; literary writing as a path to comprehending social contradictions; Lukács and the particularity aesthetics.

\section{Recebido em 04 de fevereiro de 2014}

Aprovado em 20 de maio de 2014

BASTOS, Hermenegildo. Os coronéis - de Mendonça a Paulo Honório: notas sobre tipicidade e realismo em S. Bernardo. Revista do Instituto de Estudos Brasileiros, Brasil, n. 6o, p. I8-33, abr. 2015. DoI: http://dx.doi.org/Io.II606/issn.23I6-90IX.voi6opI8-33

I Universidade de Brasília (UnB, Brasília, DF, Brasil). 
No segundo capítulo, tratando do projeto de escrever o livro após ver fracassada a tentativa de fazê-lo pela divisão do trabalho, Paulo Honório declara a sua intenção de contar a sua história, o que, entretanto - ele avalia - será difícil ${ }^{2}$. De fato trata-se da dificuldade de escrever. A sua colocação inicial não deixa ver a amplitude da questão: o personagem que decide escrever e que já em outro momento se sente simplesmente obrigado a fazê-lo; a necessidade de selecionar os acontecimentos, o que o leva a dispensar o acessório e acidental; a sociedade representada e o modo de representá-la, a problematização da configuração; as relações entre o personagem-escritor e os outros personagens, as contradições irresolvidas; tudo se funde com um alto grau de complexidade. A história já passou, mas o leitor acompanha a narração como algo que se dá aqui e agora à sua vista. O modo de representar não é externo ao mundo representado, é parte dele, mas evita se anular, luta por se distanciar, preservando sempre o tom crítico.

Como se pode ver, a dificuldade não é apenas do narrador, mas do autor, e só é daquele na medida em que este, colocando em cena mais um personagem escritor elemento central da sua obra -, vale-se desse recurso para problematizar a literatura num momento em que o Modernismo brasileiro sofre, como afirma Lafetá em ensaio hoje clássico, uma mudança de ênfase, ou de ângulo, passando a se preocupar mais diretamente com os problemas sociais ${ }^{3}$.

Graciliano, como se sabe, tinha uma posição crítica perante o Modernismo, do qual, entretanto, herdou muitas das conquistas. Os historiadores e críticos mais atentos perceberam que, mantendo-se fiel ao realismo do século XIX, Graciliano, porém, não deu às costas aos avanços estéticos do Modernismo.

A proposta crítica elaborada por João Luiz Lafetá revela hoje, num momento em que o Modernismo cede lugar a outras formas de representação e torna-se, também ele, um fenômeno do passado literário, um significado ainda maior do que parecia ter à época em que foi publicada (início dos anos I970). Na primeira fase do Modernismo, diz Lafetá, não existia consciência da possibilidade ou da necessidade de uma revolução proletária. Já o decênio de I930 é marcado, no mundo inteiro, por um recrudescimento da luta ideológica. Como essa diferença se manifesta na literatura (como tema, mas

2 RAMOS, Graciliano. S. Bernardo. Rio de Janeiro/São Paulo, Record, 20I3, p. II.

3 LAFETÁ, João Luiz. I930: a Crítica e o Modernismo. São Paulo, Duas Cidades/34, 2000, p. 30. 
não apenas, pois tensiona o ritmo do pensamento e da escrita), eis a dificuldade com que se defrontam o personagem-narrador, o escritor e o leitor.

Ainda segundo Lafetá, nos anos I930 o Modernismo atinge a maturidade e o equilíbrio, caminhando já então para a diluição. Nos anos I920, a grande discussão é eminentemente literária e se dá em torno da questão da linguagem. Já nos anos I930 coexistem a maturidade e a alta qualidade da arte modernista e o início da diluição da sua estética, que se torna então "rotinizada" - expressão de Antonio Candido que Lafetá cita. Os dois momentos (a primeira e a segunda geração) compõem uma unidade que, entretanto, não é pacífica, é tensa. Lafetá discerne na história do Modernismo um projeto estético e um projeto ideológico. Na verdade, diz ele, o projeto estético já contém em si o projeto ideológico. Há entre os dois uma complementaridade, mas não se podem esquecer os "pontos de atrito e tensão entre eles"4.

Perante os problemas abertos pelo Modernismo, mas do modo crítico já referido, Graciliano publica em I934 S. Bernardo. É partir daí que se deve considerar a centralidade da questão da escrita no livro. No romance, Paulo Honório tem a intenção de escrever a sua história. Escrever a sua própria história pressupõe que ela seja exatamente isso - uma história, não obrigatoriamente excepcional, mas também não banal, sim que represente algo mais do que a mera individualidade. $\mathrm{O}$ que o leitor terá pela frente será a luta do personagem por superar "o caráter fugidio, meramente superficial, casual" da singularidade5. Paulo Honório é um coronel assassino do Nordeste dos anos I930 igual a outros tantos. Não deixará de sê-lo. Mas aí reside a dificuldade da escrita: uma história de coronel igual a tantos outros só ganhará sentido se chegar a ser uma "generalização significante", não uma média estatística. O caminho é o da depuração que leva ao concreto, superando o empírico e imediato como também a abstração conceitual. O leitor acompanha as mediações que levarão ao concreto - a configuração de Paulo Honório.

O meramente contingente ou casual não é matéria da poesia. Já Aristóteles na Poética conceitua a diferença entre a crônica e a poesia, afirmando que enquanto aquela narra acontecimentos meramente contingentes, singulares, casuais, sem inteligibilidade, esta narra as conexões entre os acontecimentos, conferindo-lhes universalidade e inteligibilidade ${ }^{6}$.

A diferença entre a crônica (como narrativa do que aconteceu ou acontece, que se impõe ao homem pela facticidade e inexorabilidade) e a poesia (como narrativa dos possíveis e, portanto, do sentido do destino humano e da liberdade) será retomada por Lukács, mas de modo agora dialético: o casual ou contingente e o necessário ou universal estão indissoluvelmente ligados.

Segundo Lukács, Aristóteles não pôde colocar a questão do típico, ou seja, da indestrutível unidade de singular e universal, em decorrência de limitações do seu momento histórico. A poesia não é o oposto da história, sim o seu contraposto dialético. Aquilo que pode acontecer é um conjunto de possibilidades presentes no

4 Idem, p. 2I.

5 LUKÁCS, Georg. Introdução a uma Estética Marxista. Sobre a Particularidade como Categoria da Estética.

Rio de Janeiro, Civilização Brasileira, I970, p. 236.

6 ARISTÓTELES. Poética. Porto Alegre, Globo, I966. (IX I45Ib). 
mundo objetivo, isto é, na esfera do que aconteceu ou acontece. O efeito estético deve ser entendido, então, como o resultado de um processo no mundo real, não apenas no mundo da arte como algo isolado.

Do ponto de vista de Lukács, a poesia tem um papel na história, que consiste em evidenciar a essência ocultada pelas aparências da imediatez da vida cotidiana. A arte, diferentemente da ciência, não pode superar o contingente na necessidade. A sua intenção é mostrá-lo na sua intricada relação com a necessidade, na relação de ação recíproca que se manifesta na própria vida.

Aqui se põe o conceito de realismo como um modelo de narrativa que evidencia as possibilidades históricas reais: o que pode acontecer emergindo do que acontece. A arte pertence, pois, à esfera do possível, mas não o possível desvinculado do mundo real e sim a ele dialeticamente ligado. A dialética da arte está em que ela representa os limites estruturais do mundo objetivo e as possibilidades de sua superação. A narrativa será realista, na perspectiva lukacsiana, se representar essas possibilidades, ainda que em forma de possibilidades extremas, postas em situações extremas. O realismo é uma orientação para o futuro, em que poderão se efetivar as possibilidades extremas.

Assim, as “dificuldades" da escrita literária - não apenas da escrita da história de Paulo Honório - estão em que a poesia deve ir além da narrativa episódica, precisa atingir o universal, sem apagar o singular, revelar a essência sem renegar a aparência.

Na Poética o mito, diferentemente da narrativa episódica, é uma unidade de ações. Mas não quaisquer ações, sim ações com conteúdo significativo para a comunidade - ações éticas, práxis. A poesia é também uma ação, mas de outro tipo - uma ação produtiva. A ação produtiva do poeta (poesia) é imitação de ações éticas (práxis). Disso decorrem duas coisas complementares: I) a poesia é uma ação, não um estado de texto nem uma essência atemporal; 2) a ação do poeta é a de dar unidade ao mito - que é o que devemos entender por "verossimilhança e necessidade", como aparece no capítulo 9 da Poética. As ações, que inicialmente aparentam não ter sentido, ao final tornam-se verossímeis (ou inteligíveis). A ação do poeta é, então, a de provocar a catarse: pelo efeito catártico o leitor encontra o sentido que anteriormente não era perceptível.

Em S. Bernardo o caráter do personagem emerge de suas ações. Para se descrever, Paulo Honório precisa apenas de algumas linhas. Ele tenciona escrever a sua história, mas o seu objetivo na vida foi tomar posse da fazenda S. Bernardo: a história do personagem se entende como a história desta ação que ele, ao final, percebe como desumanizadora. A tomada de consciência pelo personagem do caráter desumanizador não muda a sua condição. Mas como processo catártico aponta para novos caminhos, que são então possibilidades extremas: um mundo outro é necessário e, mais do que isso, urgente.

Em “O romance como epopeia burguesa”, Lukács observa que para representar a relação real do homem com a sociedade e a natureza (isto é, não somente a consciência que o homem tem dessas relações) o único caminho adequado é a representação da ação, somente na ação a verdadeira essência do homem encontra sua expressão7.

7 LUKÁCS, Georg. O Romance como Epopeia Burguesa. In: Arte e Sociedade. Escritos Estéticos I932-I967. Rio de Janeiro, UFRJ, 2009, p. 205. 
Tomar posse de S. Bernardo fará desse coronel assassino o objeto da narrativa. Ele precisa eliminar muitas coisas e pessoas, até chegar a ser quem é: precisa se distinguir dos outros coronéis iguais a ele, inclusive, até certo ponto, dele próprio. O leitor de $S$. Bernardo não confundirá, por exemplo, a voz e a dicção do personagem que é preso por ter esfaqueado o Fagundes com a voz e a dicção do Paulo Honório que se lamenta por não ter podido entender Madalena.

Casimiro Lopes, a seu mando, mata Mendonça. Com isso resolve-se um problema de demarcação de terras, mas também um problema de caracterização: eliminado Mendonça, Paulo Honório se sobrepõe, pela violência, à infinidade dos outros coronéis. Habilita-se a ser o catalizador das ações que deveriam ser transformadoras. $\mathrm{O}$ fato dessas ações não terem resultado em nenhuma transformação efetiva coloca um problema a mais de que tratarei mais adiante.

Esfaquear Fagundes é uma ação relativamente banal, a despeito de sua violência. Difere de mandar matar Mendonça. No momento em que Casimiro Lopes mata Mendonça, Paulo Honório está exercendo o seu poder, corrompendo o representante da Igreja, o Padre Silvestre, comprometendo-se a construir uma igreja na fazenda. Tem um álibi, mas todos sabem do seu envolvimento com o assassinato. É uma violência institucionalizada, consentida, tornada marca do personagem e também da sociedade.

Paulo Honório não tem ascendente. Não tem pai nem mãe conhecidos. Trabalhou no eito da fazenda S. Bernardo, propriedade decadente que ele então quer revigorar. Pretende ser o iniciador de uma nova linhagem. É um coronel sem tradição, o que de certa forma quebra a lógica da herança patriarcal. Mas por isso também viu fracassarem os seus projetos.

A violência é mais do que um mero traço do caráter de Paulo Honório. É pela violência que ele se torna Paulo Honório, eliminando obstáculos materiais ou humanos, eliminando os outros seres em que ele poderia se tornar - o descendente da velha Margarida, o bom almocreve, por exemplo.

Ele traça o seu destino, ou julga fazê-lo - apossar-se de S. Bernardo, modernizar a fazenda e a vida econômica local, ser o fundador de uma nova geração, fabricar o seu filho e herdeiro, preservando, porém, as mesmas formas arcaicas de exploração do trabalhador do campo e de relações humanas e amorosas. Para tanto põe em ação um verdadeiro exército de colaboradores e cúmplices - professora, padres, juízes, advogados, jornalistas etc. Os conflitos que surgem entre eles não desfaz a cumplicidade, devem ser entendidos como partes "naturais" dela.

A força de S. Bernardo, diz Antonio Candido, parece provir da unidade violenta que o autor lhe imprimiu ${ }^{8}$. E ele acrescenta: os personagens e as coisas surgem nele como meras modalidades do narrador, ante cuja personalidade dominadora se amesquinham, frágeis e distantes. Mas Paulo Honório, por sua vez, é modalidade duma força que o transcende e em função da qual vive: o sentimento de propriedade.

A construção de $S$. Bernardo é a construção de Paulo Honório, a construção de um tipo. Este Paulo Honório que conhecemos se efetiva eliminando outros que inicialmente disputam com ele a centralidade do tipo e que não desaparecem de todo. $\mathrm{O}$ tipo se modifica, pois. E a permanência dos outros Paulo Honório evidencia a tensão

8 CANDIDO, Antonio. Fiç̧ão e Confissão. Rio de Janeiro, Ouro sobre Azul, 2006, p. 32. 
presente no mundo figurado: a sociedade se reproduz, mas o processo mesmo dessa reprodução é contraditório. Captar e narrar esse processo - eis a escrita difícil.

A construção do tipo pode ser avaliada se confrontamos Paulo Honório com outros personagens, porque é no e do confronto que o tipo se forma. No confronto eles tendem a ser anulados, mas permanecem vivos de alguma maneira no próprio Paulo Honório e em alguns momentos se individualizam e conseguem acenar para as alternativas que representam e que insistem em não desaparecer. Lukács fala de hierarquia de tipos como fundamento ideal da composição. Aí também não se pode falar de figuras fixas, sim de um processo ininterrupto de mediações.

A permanência desses personagens na sua relação com Paulo Honório assinala as contradições da sociedade representada. A escrita difícil se realiza quando consegue revelar nessas relações pessoais contraditórias o conjunto da vida social. Não podemos tomar isoladamente este ou aquele personagem, mas as relações entre eles, o conjunto das contradições.

Pensamos imediatamente no par Paulo Honório-Madalena, o mais evidente: o par marido-esposa, formado por um sentido de dominação, mas de tal forma que o aniquilamento dela leva ao aniquilamento dele. Madalena seria a versão "boa" de um capitalismo modernizador que, pela necessidade premente de concentração, precisa assumir claramente a versão "má". Entretanto, mesmo sendo suprimida, a versão "boa" evidencia a contradição irresolvida. Isto porque a versão "má", vitoriosa, contudo não deu os resultados esperados por Paulo Honório. No momento em que ele contempla o seu fracasso, a Revolução de 30 já ocorrera, a economia e a política capitalistas continuam a seguir o seu caminho devastador. A paralisia é dele, não dos seus concorrentes. A versão "má" o suprime também.

Em seguida, pensamos na identidade assinalada pelo próprio narrador entre Paulo Honório e Casimiro Lopes: talvez os dois fossem uma pessoa só. Uma só pessoa não são, mas Casimiro Lopes é mais do que o jagunço a serviço do coronel. Ele pode fazer os serviços que o coronel não faz, desempenhando o seu papel, materializando-se nos momentos em que ele precisa desaparecer, em suma confundindo-se com ele. Matando Mendonça, Casimiro Lopes realiza a ação que tornará possível o caminho de Paulo Honório.

Também Paulo Honório e Mendonça formam um par. São dois coronéis separados por uma cerca. São rivais, mas estão unidos na defesa da propriedade, não esta ou aquela propriedade, mas a propriedade como tal. Dela eles são simples instrumentos. Eliminando Mendonça, porém, Paulo Honório pode vir a ser quem é. Paulo Honório quer renovar as formas do capitalismo, enquanto Mendonça representa o capitalismo que deve desaparecer para dar lugar às formas novas de acumulação e dependência. $O$ instrumento toma consciência de si como instrumento.

Paulo Honório e Padilha estão ligados pelo desejo que ambos têm pela fazenda. Paulo Honório toma a fazenda de Padilha para transformá-la: ela deixará de ser uma mistura de bucolismo com inércia para se tornar um empreendimento capitalista efetivo. Contudo, ao final, não está Paulo Honório reduzido à condição de Padilha? $\mathrm{O}$ empreendimento capitalista frustrou-se e o significado afetivo da fazenda, que inicialmente distingue Padilha de Paulo Honório, ao final os iguala - como se uma vingança do primeiro. 
Paulo Honório e seu Ribeiro formam outro par: se o primeiro consegue, por algum tempo, pilotar o automóvel que atropelou seu Ribeiro, ao final termina também atropelado pelo mesmo "automóvel". A história de seu Ribeiro vem no capítulo 7. Aí Paulo Honório sentencia: "Tenho a impressão de que o senhor deixou as pernas debaixo de um automóvel, seu Ribeiro. Por que não andou mais depressa? É o diabo". A simpatia que Paulo Honório demonstra por seu Ribeiro trai o desejo de que a pequena aristocracia rural que ele representava conseguisse andar mais depressa, evitando ser atropelada? A modernização, então, seria menos violenta? Essa perspectiva não é decisiva, mas ronda a narrativa. Este Paulo Honório jamais desaparece de todo, como um passado jamais superado.

Enfim, o Paulo Honório que conhecemos e um outro ao modelo do romance pitoresco:

Se houvesse continuado a arear o tacho de cobre da velha Margarida, eu e ela teríamos uma existência quieta. Falaríamos pouco, pensaríamos pouco, e à noite na esteira, depois do café com rapadura, rezaríamos rezas africanas, na graça de Deus. Se não tivesse ferido o João Fagundes, se tivesse casado com a Germana, possuiria meia dúzia de cavalos, um pequeno cercado de capim, encerados, cangalhas, seria um bom almocreve. [...] E em manhã de invernos, [...] beberia um gole de cachaça para espantar o frio e cantaria por estes caminhos, alegre como um desgraçado. ${ }^{\text {Io }}$

Paulo Honório pensa no outro Paulo Honório no momento de autoconsciência, o que é outra coisa diferente da consciência que o instrumento tem de si como instrumento. Agora Mendonça já morrera e o projeto fracassara. Paulo Honório contempla a sua construção - ele próprio - como um destroço. Na peripécia a vitória transforma-se em derrota.

Outros personagens poderiam ser analisados nessa perspectiva. Mas o que importa aqui é sublinhar as relações que permitem ver as tensões conformadoras do tipo, que se mostra então como um processo ininterrupto de mediações ${ }^{\mathrm{II}}$.

O típico não é, torna-se - afirma Lukács. Como categoria, da mesma forma que a singularidade e a universalidade, é determinação da existência, não apenas do conhecimento. Singularidade, particularidade e universalidade são categorias da vida. O movimento dialético da realidade é ininterrupto, vai do singular para o universal e deste, novamente, para aquele. A particularidade, ou tipo, não é jamais um ponto fixo, é um inteiro campo de mediações. Não é uma faixa amorfa de ligação entre o singular e o universal. O particular se converte dialeticamente em universal e de volta em singular.

Essa concepção do tipo corre sempre o risco de se perder numa estética normativa. Para não cair nela, é preciso entender que o processo de mediação é ininterrupto e

9 RAMOS, Graciliano. S. Bernardo, op. cit., p. 46.

Io Idem, p. 2I8-2I9.

II Em estudo sobre Paulo Honório, Benjamin Abdala Junior explora também o contraponto entre Paulo Honório e outros personagens do romance, sem colocar, porém, a questão da tipicidade. Cf. ABDALA JUNIOR, Benjamin. O Pio da Coruja e as Cercas de Paulo Honório. In: MOTA, Lourenço Dantas. Personae. Grandes Personagens da Literatura Brasileira. São Paulo, Senac, 2001. 
ocorre na vida real antes que na arte. Cada tipo fixado se modifica continuamente. Em "Arte e verdade objetiva”, a propósito das leis aristotélicas da tragédia, Lukács contrapõe Lessing, para quem o que importa é a essência viva das leis da tragédia, aos clássicos franceses que eram "discípulos dogmáticos servis das palavras de Aristóteles". Shakespeare, afirma Lukács, que talvez nem sequer conheceu Aristóteles, "cumpre integralmente as leis da tragédia" ${ }^{\text {ז2 }}$.

Assim como a Poética de Aristóteles, a poética do realismo de Lukács não deve se enrijecer e se tornar um mero conjunto de normas. Se Shakespeare, sem conhecer Aristóteles, cumpre as leis da tragédia, é porque essas leis pertencem à vida social, antes de pertencer a esta ou aquela poética. A validade da poética ou da teoria crítica está em captar e formular essas leis. Lukács em diversos momentos afirma que os artistas anteciparam-se em muito à compreensão dos críticos e estetas dos fenômenos artísticos.

A particularidade é esse processo de mediações que ocorre antes na vida do que na arte. Assim, é possível e, mais do que isso, necessário entender que a estética da particularidade modifica-se também se saímos da literatura europeia dos países capitalistas avançados e caminhamos para os países europeus do capitalismo atrasado (a Alemanha, por exemplo) e mais ainda para as áreas da expansão colonialista (o Brasil, por exemplo).

Lukács sublinha o mérito de Hegel em ter reconhecido a dialética de universal e particular na Revolução Francesa, ou seja, no processo histórico mais do que simplesmente no pensamento. As velhas classes dirigentes já não representavam os interesses de toda sociedade (o universal), na verdade pretendiam apenas defender os seus próprios interesses de classe (o particular). A burguesia, como nova classe revolucionária, deve se apresentar - ainda que de fato também defenda seus próprios interesses de classe (o particular) - como representante de toda sociedade. A importância de Hegel está em "[...] ter tratado de um problema exclusivamente lógico em aparência, como é o caso da relação do universal com o particular e o singular, como um problema da estrutura e do desenvolvimento da sociedade" ${ }^{\text {I3. }}$.

Mas Marx, diz Lukács, não podia aceitar esse esquema abstrato. Na Crítica da Filosofia do Direito de Hegel, Marx fala da revolução, tendo já no horizonte a revolução proletária, como de um momento em que as exigências e direitos de uma classe são as exigências e direitos de toda a sociedade. Hegel assume a contradição do fenômeno como unidade na essência, na ideia. Com Marx, o universal e o particular deixam de ser imagens reflexas abstraídas de reais situações sociais. Em lugar de reconhecer por toda parte as determinações do conceito puro, é preciso conceber a lógica específica do objeto específico. Lukács acentua a impossibilidade de se deduzir dos processos histórico-sociais um "esquema qualquer". É preciso esclarecer a forma concreta de uma determinada situação social e descobrir a que direção apontam as transformações sociais.

I2 LUKÁCS, Georg. Arte y Verdad Objetiva. In: Materiales sobre el Realismo. Barcelona/Buenos Aires/

Cuauhtémoc, Ediciones Grijalbo, I977, p. 223.

I3 Idem. Introdução a uma Estética Marxista, op. cit., p. 76. 
A concepção estética lukacsiana sofreu algumas mudanças (sem abalar os princípios) na passagem dos estudos sobre o realismo francês e russo para os estudos sobre os realistas alemães do século XIX e na história da literatura alemã. Se o tipo é aquele processo ininterrupto de mediação, o que importa é entender cada momento determinado.

Sendo um processo ininterrupto de mediação, o típico não pode estar fixado no passado, sim na transformação do passado em presente e apontando para o futuro. Como tal, o modelo lukacsiano da particularidade não se fecha no século XIX europeu. Em ensaios tardios sobre escritores como Jorge Semprun e Soljenitsin, ele deu claras indicações da possibilidade e da necessidade de estender a outras literaturas e escritores a sua concepção de realismo.

É preciso também considerar, o que não poderei fazer aqui, que Lukács é um pensador húngaro, um pensador, portanto, que, embora tenha assimilado como poucos a tradição filosófica e literária ocidental, não pode ocultar um ponto de vista deslocado do centro.

Nos Manuscritos Econômicos Filosóficos, Marx já assinalava o caráter ao mesmo tempo nacional e internacional do capitalismo. O realismo literário, como tratado por Lukács, tem também este caráter duplo: o caminho que veio de Goethe a Scott, a Balzac e a Tolstoi levou ao capitalismo mundializado e à entrada em cena de outras literaturas que não as europeias.

A pergunta que se coloca é se o processo de mediação pode sofrer algum tipo de estagnação. Em outras palavras: se o modelo lukacsiano elabora a historicidade correspondente a momentos de transformação no espaço europeu, e sempre na expectativa da revolução proletária, o que acontece então quando saímos desse espaço e necessitamos reelaborar a historicidade dos novos momentos?

Sabem os leitores de Lukács que essa questão gerou cisões ainda hoje insuperadas no interior da teoria e da crítica literária marxista. Não pretendo entrar nessa discussão aqui e agora. Gostaria, pelo contrário, de discutir a estética lukacsiana com os desafios que ela coloca para si mesma. O desafio está em, evitando os perigos normativos, preservar a ideia básica da particularidade como um processo ininterrupto de mediação. Na estética, como também na política, continuamos a lidar com as dificuldades de entender o capitalismo, as suas crises e a sua capacidade aparentemente infinita de superá-las.

Mas então como tratar uma situação periférica como a brasileira dos anos I930 representada em S. Bernardo? A periferia pode em casos concretos evidenciar o cerne do processo histórico, como acontece na obra de Machado de Assis no final do século XIX: narrando o Brasil dos Oitocentos, Machado de Assis dá a ver o sistema-mundo capitalista do ponto de vista da periferia.

Em estudo recente, Moretti compara Balzac a Machado de Assis e as suas diferentes formas de representação da passagem do velho regime para a modernidade capitalista. Foca em As Ilusões Perdidas e em Memórias Póstumas de Brás Cubas dois episódios de relações humanas mediadas pelo dinheiro. Em Balzac o editor Doguereau dispõe-se inicialmente a dar mil francos ao candidato a escritor Lucien de Rubempré; depois, conhecendo as suas péssimas condições de vida, reduz uma, duas e três vezes a quantia inicial. Trata-se aí de uma relação claramente capitalista: relações pessoais jamais 
entram em cena. Nas Memórias Póstumas, Brás Cubas é salvo pelo almocreve de um tombo do burro que poderia ter sido fatal. Inicialmente tocado pelo acontecimento, pensa em recompensar o almocreve com uma quantia generosa, mas que diminui também uma, duas, três vezes. Ao final dá-lhe apenas um cruzado de prata. Diferentemente do que ocorre com Balzac, em Machado não há nada objetivo. Brás Cubas sente remorsos ${ }^{\mathrm{I}}$. Moretti apoia-se na leitura que Roberto Schwarz faz das Memórias ${ }^{\text {I5 }}$. A realidade burguesa subordina-se à arbitrariedade pessoal. É uma vitória do capricho. Moretti assinala as malformações do capitalismo semiperiférico. Aí a conflituosa coexistência entre capitalismo e antigo regime leva ao triunfo do último, como numa crônica das derrotas burguesas.

Interessa-nos aqui algo não contemplado por Moretti: em S. Bernardo o momento em que Paulo Honório dá o golpe final em Padilha parece mais próximo de Balzac do que de Machado. Aí não há capricho e Paulo Honório não sente remorso:

Para evitar arrependimento, levei Padilha para a cidade, vigiei-o durante a noite. No outro dia, cedo, ele meteu o rabo na ratoeira e assinou a escritura. Deduzi a dívida, os juros, o preço da casa, e entreguei-lhe sete contos quinhentos e cinquenta mil-réis. Não tive remorsos. ${ }^{16}$

Em S. Bernardo trata-se também das malformações do capitalismo semiperiférico e da vitória do antigo regime sobre a burguesia. De qualquer modo, porém, não parece ser a arbitrariedade pessoal que dá o tom aí. Também não se trata de nenhuma mudança substancial da má condição brasileira. Mas a propalada preferência de Graciliano pelo realismo oitocentista talvez possa ser entendida a partir daqui, não apenas como uma preferência pessoal ou sinal de passadismo, mas de um modo que nos permita ver os embates entre realismo e modernismo em perspectiva histórica, ou seja, que nos permita ver mais claramente as contradições da dependência brasileira, das quais o fazer literário é parte significativa.

O leitor de $S$. Bernardo percebe que a história aí narrada é mais do que uma história local do Nordeste brasileiro dos anos I930. Há indicações suficientes para que se perceba que os acontecimentos (incluindo a compra de máquinas, a importação de novilhos etc.) são nacionais. A conexão entre os acontecimentos é inicialmente econômica, mas é ela que determina também os limites sociais, morais, existenciais da vida dos personagens. Além disso, as opções literárias do escritor respondem a uma situação nacional e também mundial.

S. Bernardo é uma narrativa em primeira pessoa, de caráter confessional, o que nos coloca problemas especiais. O ponto de vista é o do personagem-narrador, que é a manifestação mais forte do seu domínio. “Tenciono contar a minha história” - diz ele. E quando começamos a ler a narrativa e nos inteiramos dos problemas de composição,

I4 MORETTI, Franco. Balzac, Machado and Money. In: The Bourgeois. Between History and Literature.

London/New York: Verso Books, 20I4.

I5 SCHWARZ, Roberto. Um Mestre na Periferia do Capitalismo. Machado de Assis. São Paulo, Duas Cidades, I990.

I6 RAMOS, Graciliano. São Bernardo, op. cit., p. 30. 
a história já acabara. Paulo Honório se confessa violento, possessivo, dominador. Se tudo começasse de novo, seria tudo igual. Ele reconhece que não estava à altura de Madalena, mas não poderia mudar nada. Nem consegue ser o fundador de uma nova linhagem, como queria. Quando a narrativa começa, ele já tomara consciência disso. É a narrativa de um limite, que não é meramente pessoal, mas social e nacional.

O ponto de vista não é o de um eu preso na própria subjetividade. Em $S$. Bernardo "a historiografia da vida privada" não se rebaixa, como observa Lukács a propósito de Fielding, Restif de la Bretone e Balzac, ao nível da crônica banal ${ }^{\mathrm{I7}}$. Os conflitos com Madalena não são meros conflitos pessoais, ou melhor, são pessoais, mas ao mesmo tempo dão a ver as contradições sociais. O interior converte-se no exterior e este naquele. A violência é o espaço do drama pessoal e coletivo e sempre evidencia a crítica à vida. Não há conformismo nessas páginas ásperas, mas recusa da ordem. Paulo Honório é o nome de um estado de mundo - o da reificação - e da urgência de superá-lo.

A vida privada, diz ainda Lukács, é o verdadeiro material do romance, porque na sociedade moderna separam-se as funções sociais e as questões privadas. Este é o quadro da sociedade capitalista, a sua contradição básica - produção social e apropriação individual. Por isso a busca do páthos na sociedade moderna tem que seguir na direção da vida privada. A unidade imediata do universal e do singular que caracterizava a sociedade guerreira e a epopeia é inatingível na sociedade moderna. Para o escritor moderno o páthos da vida privada "só pode ser encontrado por meio de caminhos muito indiretos e complexos": as forças sociais (o universal) devem aparecer na vida do personagem individual concreto (o singular). Só por esses caminhos assim complexos o romancista pode representar a particularidade e o típico.

A história que se desenrola a nossa frente é então também a história da escrita, difícil. Não é à toa, portanto, que o personagem quer escrever, embora sem ter as condições necessárias para tal.

A dificuldade aí colocada explicitamente no segundo capítulo, mas presente em cada página, parágrafo e palavra, é a de todo escritor: escrever literatura não é uma questão de mera capacidade (acadêmica, gramatical, institucional), é a questão de poder captar a totalidade social, o sentido dos destinos humanos, os nexos existentes mas ocultados na vida cotidiana. Lukács, ao tratar dos problemas da forma típica, diz que a arte tem a capacidade de suscitar experiências, fala então da função evocadora da elaboração formal ${ }^{18}$. A questão colocada em $S$. Bernardo é esta: teria a sua escrita a capacidade de suscitar experiências, de evocar aquela realidade, captá-la pelo seu nervo estético típico, sem se perder no exotismo e no pitoresco? Seria a escrita capaz de evocar a velha Margarida, Marciano, Padilha, Gondim, Casimiro Lopes, mestre Caetano, Rosa e, sobretudo, Madalena, os seus destinos e situações singulares e o mundo particular em que esses momentos singulares, reforçando-se e integrando-se reciprocamente, dão vida ao conjunto?

O que ocorre em S. Bernardo é que esses desafios são postos pelo escritor Graciliano Ramos e nós leitores somos levados a tomá-los, ao menos até um certo momento, como

I7 LUKÁCS, Georg. O Romance como Epopeia Burguesa, op. cit., p. 209.

I8 Idem. Introdução a uma Estética Marxista, op. cit., p. 252. 
desafios do personagem-escritor. O narrador, Paulo Honório, fala da sua atividade de escritor, de modo a deixar intrigado o leitor quanto à veracidade das suas afirmações sobre a feitura da obra. Rui Mourão observa que o projeto de produção do livro pela divisão do trabalho "soa-nos inteiramente fora de propósito", mas os leitores são levados a aceitá-lo como uma ironia ${ }^{\text {T9 }}$. Mais à frente, entretanto, quando o narrador especifica o trabalho que caberia a cada um dos participantes do projeto, referindo-se a cada um deles como a alguém familiar ao leitor, então este percebe o "plano literário". Mourão diz ainda que, quando por fim somos informados de que a Lúcio Gomes de Azevedo Gondim caberia a composição literária, vemos que não é Graciliano Ramos que está com a palavra. O personagem sai da pena do escritor já com dimensões próprias, ganhando independência: "[...] acompanhamos, diz Mourão, o personagem no seu movimento de se destacar do tempo do autor e se inserir no seu próprio contexto"20.

Esse artifício foi muito bem explorado pelo romancista e só aos poucos tomamos consciência dele como artifício. Mourão destaca ainda a inabilidade do narrador e seu estilo claudicante e sua imperícia. Cabe ao leitor perceber, não sem dificuldade, que o autor Graciliano Ramos produz a representação desse escritor e sua escrita inábil e claudicante e que essa representação é funcional. O leitor se demora entre a excelência do escritor Graciliano Ramos e a imperícia do personagem-escritor que se utiliza de processos antiquados de começar a história pela identificação do autor, seu nome, idade e peso etc. À medida que a narrativa evolui o leitor acostuma-se à ambiguidade, chegando mesmo a esquecê-la. Contudo, ela continua tendo um sentido: a atividade literária é parte central da representação do romance.

A obra que lemos é de Graciliano Ramos, mas o leitor é defrontado com aquela ambiguidade cujo significado ele precisará captar. Essa perspectiva parece muito mais significativa do que a de Álvaro Lins, que fez restrições a S. Bernardo porque, segundo ele, o romance pecaria por inverossimilhança dado o contraste do livro e seu imaginário escritor ${ }^{21}$. Fica claro que Álvaro Lins tomou o conceito de verossimilhança de modo muito restrito, uma vez que não considerou as observações de Aristóteles no capítulo XVIII da Poética. Aristóteles comenta Agatão quando este afirma que "verossimilmente muitos casos se dão e ainda que contrários à verossimilhança"22.

Em S. Bernardo as discussões sobre literatura dão a ver aquilo que chamei em estudo sobre Memórias do cárcere de autoquestionamento ${ }^{23}$. Não a literatura fechada em si mesma, abismada em si mesma, mas a literatura que questiona a sua razão de ser, como prática discursiva de uma determinada sociedade.

A dificuldade da escrita - Paulo Honório continua a refletir ainda no segundo capítulo - está na relação com os leitores. O que é relevante mencionar? Ele está

I9 MOURÃO, Rui. Estruturas. Ensaio sobre o Romance de Graciliano. Rio de Janeiro, Arquivo Editora/INL/ MEC, I97I, p. 55.

20 Idem, p. 56.

2I LINS, Álvaro. Valores e Misérias de Vidas Secas. In: Ramos, Graciliano. Vidas Secas. Rio de Janeiro/São Paulo, Record, I986, p. I47.

22 ARISTÓTELES. Poética, op. cit., XVIII I456a 23.

23 BASTOS, Hermenegildo. Memórias do Cárcere. Literatura e Testemunho. Brasília, UnB, I998. 
habituado com matutos e, por isso, talvez não confie suficientemente nos leitores. Em meio a tantos argumentos reais ou fingidos, percebemos o gesto de desqualificação dos matutos, por um lado, por outro dos leitores. O leitor real que quiser ultrapassar as dificuldades aí colocadas propositalmente deverá se diferenciar dos matutos e daqueles leitores acostumados com uma literatura "bem comportada".

Paulo Honório é versado em estatística, pecuária, agricultura, escrituração mercantil - conhecimentos que chamamos práticos para diferenciar das belas-artes. Acentuar isso, ao mesmo tempo em que aponta para a divisão do trabalho é lembrar as condições atrasadas da economia brasileira, mas também o comprometimento da literatura com a luta pela vida. Não é só pela referência à divisão de trabalho que o leitor percebe a escrita de $S$. Bernardo intrinsecamente ligada à vida econômica: as escolhas estilísticas - reais ou fingidas - são (ou pretendem ser) forças produtivas.

Se na primeira geração modernista a literatura brasileira pretendia ser uma forma de conhecimento do país, na segunda ela pretende ser uma luta por transformá-lo. O romance era como uma força de transformação, como uma força produtiva. (A propósito disso, na crônica "O fator econômico no romance brasileiro" ele expõe suas concepções sobre a relação entre literatura e economia. ${ }^{24}$ )

Quando Paulo Honório se pergunta, já depois de ver frustrado o seu plano inicial, para quê escreve e responde "sei lá", a questão é tangenciada, mas o leitor deverá participar da formulação da resposta. As conversas e desconversas não são falsas: revelam o que escondem. Agora ele já não escreve para ser importante. A literatura já não é um elemento de prestígio social. Mas nem por isso vem a ser o espaço da autopiedade.

O personagem catalisador destruiu a tudo e a todos, inclusive a si próprio. É quando então ele se volta outra vez para a literatura. Os problemas literários, como vivenciados por ele, evidenciam as questões sobre a representação literária no Brasil dos anos I930. O personagem-escritor vivencia, a seu modo e dentro dos seus limites, esses problemas.

Os problemas são vivenciados, não como problemas estritamente literários, mas como problemas de sua vida. Paulo Honório quer contar a sua história, ou mais, quer encontrar o sentido dessa história, que, sendo a da sua vida, é também a da vida de todos os outros personagens, é a situação histórica do Nordeste brasileiro e por extensão do país. É então que as questões literárias são também questões histórico-sociais e estas são questões literárias.

A figura do personagem-escritor e a do fazendeiro empreendedor e modernizador se fundem de modo admirável no romance. E isto é possível porque à literatura sempre foi conferido no Brasil, de modo contraditório, claro, um papel "modernizador".

A modernização brasileira tem tido, como têm assinalado os principais intérpretes do Brasil - de Caio Prado a Sérgio Buarque de Holanda e Celso Furtado, um caráter conservador: uma modernização que atende aos interesses periódicos de reestruturação do capital mundial e preserva as relações sociais arcaicas. Em meio a isso a literatura foi e é entre nós uma "literatura de dois gumes", como diz Antonio Candido:

24 RAMOS, Graciliano. O Fator Econômico no Romance Brasileiro. In: Linhas Tortas. Rio de Janeiro/ São Paulo, Record, I989. 
Na sociedade duramente estratificada, submetida à brutalidade de uma dominação baseada na escravidão, se de um lado os escritores e intelectuais reforçaram os valores impostos, puderam muitas vezes, de outro, usar a ambiguidade do seu instrumento e da sua posição para fazer o que é possível nesses casos: dar a sua voz aos que não poderiam nem saberiam falar em tais níveis de expressão. ${ }^{25}$

A crítica à literatura como prática social, como discurso que pode ser crítico, mas que também pode legitimar o poder, é, assim, e necessariamente, uma crítica ao processo histórico das modernizações brasileiras. Os anos I930 tiveram, como também salienta Antonio Candido em outro ensaio, uma importância decisiva nessa história contraditória. No caso da cultura, cresceu a consciência das contradições brasileiras, de tal modo que aí teve início uma fase nova com uma nova concepção de cultura no Brasil ${ }^{26}$.

O projeto de Graciliano, como também de muitos outros seus contemporâneos, e não só no Brasil, era fazer uma literatura que tivesse papel central na transformação do país, nas mudanças do sistema de posse da terra e da propriedade, que participasse da reorganização das forças produtivas e das relações de produção. Como tal, os conhecimentos técnicos sobre a administração da terra e da propriedade perdem sua estranheza inicial.

Mais à frente, já no capítulo I3 do romance, o narrador, referindo-se sempre à sua própria escrita, lamenta ter omitido a paisagem. Com isso, pensa ele, a narrativa dá ideia de uma palestra realizada fora da terra. Mas ele se explica: os canaviais são um gênero de agricultura que não lhe interessa, e os novilhos zebus são um tipo de gado que está acabando de escangalhar os nossos rebanhos. A velha paisagem bucólica não tem lugar no seu romance. É verdade que em alguns raros momentos os paus-d'arco florescem, mas é já o lamento final por Madalena. A velha paisagem é então um entrave econômico e também literário.

S. Bernardo como narrativa crítica da modernização brasileira. A consciência do caráter conservador da modernização à brasileira é o forte dessa obra. Nisso (na escrita difícil, mas capaz de representar as contradições e torná-las inteligíveis, na escrita realista, enfim) ainda consiste, a meu ver, a sua atualidade.

SOBRE O AUTOR

HERMENEGILDO BaStos Professor titular de literatura brasileira da Universidade de Brasília. Doutor pela Universidade de São Paulo. Publicação recente: As artes da ameaça: ensaios sobre literatura e crise. São Paulo, Outras Expressões, 2012.

E-mail: hjbastos@unb.br

25 CANDIDO, Antonio. Literatura de Dois Gumes. In: A Educação pela Noite e Outros Ensaios. São Paulo, Ática, I987, p. I78.

26 Idem. A Revolução de I930 e a Cultura. In: A Educação pela Noite e Outros Ensaios, op. cit., p. I95. 


\section{REFERÊNCIAS BIBLIOGRÁFICAS}

ABDALA JUNIOR, Benjamin. O Pio da Coruja e as Cercas de Paulo Honório. In: . \& MOTA, Lourenço

Dantas. Personae. Grandes Personagens da Literatura Brasileira. São Paulo, Senac, 2001.

ARISTÓTELES. Poética. Tradução, prefácio, introdução, comentário e apêndices de Eudoro de Sousa. Porto Alegre, Globo, I966.

BASTOS, Hermenegildo. Reliquias de la Casa Nueva. La Narrativa Latinoamericana. El Eje Graciliano-Rulfo. Traducción de Antelma Cisneros. Ciudad de México, Universidad Nacional Autónoma de México, Centro Coordinador y Difusor de Estudios Latinoamericanos, 2005.

. Memórias do Cárcere. Literatura e Testemunho. Brasília, UnB, I998.

CANDIDO, Antonio. A Revolução de I930 e a Cultura. In: A Educação pela Noite e Outros Ensaios, São Paulo, Ática.

. Fiç̧ão e Confissão. Rio de Janeiro, Ouro sobre Azul, 2006.

. Literatura de Dois Gumes. In: . A Educação pela Noite e Outros Ensaios. São Paulo, Ática, I987.

CLEARY, Joe. Realism after Modernism and the Literary World-System. Modern Language Quarterly, v. 73 n. 3, Sept. 20I2. Disponível em: 〈http://goo.gl/6J8zS5〉. Acesso em: I jan. 2015.

JAMESON, Fredric. Antinomies of the Realism-Modernism Debate. Modern Language Quarterly, v. 73, n. 3, Sept. 20I2. Disponível em: 〈http://goo.gl/8ImoCa〉. Acesso em: I jan. 2015.

. Modernidade Singular. Ensaio sobre a Ontologia do Presente. Rio de Janeiro: Civilização Brasileira, 2005.

KELEMAN, Janos. The Rationalism of Georg Lukács. New York, Palgrave Macmillan, 2014.

LAFETÁ, João Luiz. I930: a Crítica e o Modernismo. São Paulo, Duas Cidades/34, 2000.

LINS, Álvaro. Valores e Misérias de Vidas Secas. In: RAMOS, Graciliano. Vidas Secas. Rio de Janeiro/ São Paulo, Record, 1986.

LUKÁCS, Georg. Artey Verdad Objetiva. In: . Materiales sobre el Realismo. Barcelona/Buenos Aires/ Cuauhtémoc, Ediciones Grijalbo, I977.

. Introdução a uma Estética Marxista. Sobre a Particularidade como Categoria da Estética. Tradução de Carlos Nelson Coutinho e Leandro Konder, Rio de Janeiro, Civilização Brasileira, I970, p. 236.

.O Romance como Epopeia Burguesa. In: . Arte e Sociedade. Escritos Estéticos I932-I967. Organização, introdução e tradução de Carlos Nelson Coutinho e José Paulo Neto, Rio de Janeiro, UFRJ, 2009.

MARX, Karl. Manuscritos Económico-filosóficos. São Paulo: Boitempo Editorial, 2004.

MESZAROS, István. O Conceito de Dialética em Lukács. São Paulo: Boitempo Editorial, 2013.

MORETTI, Franco. Balzac, Machado and Money. In: .The Bourgeois. Between History and Literature. London/New York, Verso Books, 20I4.

MOURÃO, Rui. Estruturas. Ensaio sobre o Romance de Graciliano. Rio de Janeiro, Arquivo Editora/INL/ MEC, I97I.

RAMOS, Graciliano. O Fator Econômico no Romance Brasileiro. In: . Linhas Tortas. Rio de Janeiro/ São Paulo, Record, I989. S. Bernardo. Rio de Janeiro/São Paulo, Record, 2013.

SCHWARZ, Roberto. Um Mestre na Periferia do Capitalismo. Machado de Assis. São Paulo, Duas Cidades, I990. 